\title{
Research and Practice on Computer Hardware Curriculums Practical Teaching
}

\author{
Wei Zhang \\ Department of Computer Science and Technology \\ Beihua University \\ Jilin, China \\ beihuazhangwei@163.com
}

\author{
Zhong-cheng Fan \\ Department of Computer Science and Technology \\ Beihua University \\ Jilin, China \\ fanconnie@126.com
}

\begin{abstract}
The practical teaching is a very important process for students to develop their innovation abilities. In this paper, we analyzed the present state and problem of the hardware experiments teaching in university, propose opinions and suggestions of computer hardware teaching based on the experience of our reform and practice, including the practical teaching system, platform construction and teaching management and evaluation. Practice proves that the reform has achieved better results.
\end{abstract}

Keywords-Computer Hardware Curriculums; Practical Teaching; Educational Reform

\section{INTRODUCTION}

Hardware course is an important part of the computer specialized basic course. These courses are projecting the mutual osmosis and influence each other. Practice training is one of the most important ways to improve the innovative consciousness, engineering quality and comprehensive quality of students [1]. Because the influence of educational idea and teaching environment, hardware practice training can not meet the requirements of the computer education. The content of courses is outmoded, the way lags behind, the style is blankness, especially lack ability of combination of theory and practice, lack of operating method and technology, these all influence the training of the student's engineering-oriented and innovatory capacity [2]. In order to solve above problems, we introduced the practical teaching reform of hardware course in teaching management, teaching content and mode and teaching evaluation.

\section{The Reforms of Practical Teaching System}

\section{A. Divided the Courses Modules}

Hardware curriculum consists of analog and digital circuits, principles of computer composition, computer architecture etc. If the integrity and independence is overemphasizingd, much content will be teaching repeated, such as virtual memory and interrupt. So we divided the courses into four modules to emphasize different abilities goal in teaching. These modules are pilot courses, basis courses, specialized courses and elective course. A relatively complete practical platform was established after course teaching. Students can accomplish the experiments of the following course on the platform that established former. After the study of the four modules, students can master the basic working principle of the computer system and understand the development process of an application system. These will arouse student' enthusiasm and merge theory teaching and practice teaching better. The teaching system is shown in table 1 .

TABLE I. The Settings of TeAching System

\begin{tabular}{|l|l|l|l|}
\hline Order & $\begin{array}{l}\text { Course } \\
\text { Nature }\end{array}$ & \multicolumn{1}{|c|}{ Course Name } & \multicolumn{1}{|c|}{$\begin{array}{c}\text { Teaching } \\
\text { Emphasis }\end{array}$} \\
\hline 1 & $\begin{array}{l}\text { Pilot } \\
\text { Courses }\end{array}$ & Introduction to Computer & Use Computer \\
\hline 2 & $\begin{array}{l}\text { Analog and Digital Circuits; } \\
\text { Principles of Computer } \\
\text { Composition; } \\
\text { Computer Architecture; } \\
\text { The Principle } \\
\text { Microcomputer; } \\
\text { Assembly Language }\end{array}$ & $\begin{array}{l}\text { Technology } \\
\text { Foundation }\end{array}$ \\
\hline 3 & $\begin{array}{l}\text { Speciali } \\
\text { zed }\end{array}$ & $\begin{array}{l}\text { Computer Interface } \\
\text { technology; } \\
\text { Emdded Operating System; } \\
\text { Embedded System Structure }\end{array}$ & $\begin{array}{l}\text { Technical } \\
\text { Realization }\end{array}$ \\
\hline \multirow{2}{*}{$\begin{array}{l}\text { Embedded System } \\
\text { Eevelopment; } \\
\text { Computer Measurement and } \\
\text { Control }\end{array}$} & $\begin{array}{l}\text { Research and } \\
\text { Development }\end{array}$ \\
\hline
\end{tabular}

B. Breakthrough the Limitation of the Courses

In the traditional curricula, practical teaching contents were setup according to the corresponding theory teaching. The student can not combine different information together and familiar with the whole process of application system development. We set some relatively independent courses to help the students establish a vertical association among the different courses. For example, we set an engineering practice in embedded system teaching. This course will take 96 hours during 5 semesters and teaching the use of electronic component, components welding with an PCB tool, design a simple data acquisition system, develop an embedded application.

\section{THE REFORMS OF PRACTICAL TEACHING PLATFORM CONSTRUCTION}

\section{A. Constructed the Virtual Laboratory}

Purchase experiment rig or box for the construction of laboratory is very common in college and universities. But difficulty for facility maintenance and narrow range experimental influence the teaching effect. Much investment makes the renewal of equipment difficult to satisfy the teaching special requirements. So we constructed the virtual laboratory of computer hardware. The Virtual Experiment is out of the limits of time and space. In virtual laboratory, 
most experiment items can completed by the way of software simulation[3]. The problems of investment and maintenance are solved.

\section{B. Use the Network Management System in Practiclal Teaching}

Network management system of practical teaching is an effective means to improve the efficiency of teaching. The experimental booking, submission of work, put questions to teacher and viewing course content over video streamed online facilitate the practical learning. The teachers can the guide the experiment, review the experimental report and answering question online with the open laboratory management.

\section{The Reforms of Practical Teaching IMPLEMENTATION METHOD}

\section{A. Optimize teaching management and Share the resources}

To make full use of experiment equipment, we shared the equipments among the different courses and specialties. The study group and tutor group was divided according to different application fields but not to classes. Off-campus practice bases are important locations to improve students practice ability. Cooperative construction between colleges and enterprises let the students can participate in the real project and get more experience and more skills.

\section{B. The Innovation of Teaching Methods}

Modern computer teaching should change ideas to reform teaching method. We introduce new teaching methods in practical teaching such as case teaching, mutual interactive teaching to improve the students' comprehensive quality and engineering ability.

- $\quad$ Case teaching can be divided into two levels. The first level is use the engineering example in teaching, that is the course theory was explained by engineering case. The little participation can not inspire the passion of the student. The second level is carrying an engineering example in teaching. We used the second means in some practical course, such as single chip microcomputer. The development process was executed by teachers and students while they implement curriculum.

- In task drive teaching modes, teacher design and propose teaching task based on present subject teaching topic and lead students to study with practice to finish teaching task according to the idea, method and results of finishing situation $[4,5]$. The course of "The computer interface technology" was carried out through demonstrate, practice and handson experiment.

- Group Teaching was consisting of presentation, class project and grouping resistance. In "the Principle of Microcomputer" and "Introduction to Computer", we introduced this method. On the one hand, subject frontier knowledge could be discussed in group. On the other hand, complex problem could be solved cooperatively.

\section{The Reform of Teaching Evaluation}

The traditional teaching evaluation often measure students' grades by experiment report. The rigid method didn't pay attention to the teaching process. In order to overcome the defects, we establish a new index system for evaluating the quality of practical teaching to evaluate a teacher's quality of classroom teaching. We used a composite index in curriculum design evaluation to assess the students' works, table 2 shows the index.

TABLE II. THE EVALUATION INDEX

\begin{tabular}{|l|l|l|}
\hline Order & \multicolumn{1}{|c|}{ Item } & \multicolumn{1}{c|}{ Score } \\
\hline 1 & Topic & 10 \\
\hline 2 & Creativity & 30 \\
\hline 3 & Maneuverability & 20 \\
\hline 4 & Experiment Report & 10 \\
\hline 5 & Language Expression & 10 \\
\hline 6 & Design Result & 20 \\
\hline
\end{tabular}

\section{The Effect Assessment of TeAching Reform}

The reform provokes students' learning enthusiasm largely. During the past three years, our students employed in the various discipline competition actively and received more than 20 national awards. The attendance rate has been raised from $89.8 \%$ to $96.3 \%$. We investigate 300 students randomly and the data shows most students (accounting for 81.7\%) are satisfied with the reform of the teaching system. Recently, the jobs market of computer industry is severe for college graduates, but our students' employment rate has not significant decreased. All this proves the reform of computer hardware curriculums practical teaching is successful.

\section{REFERENCES}

[1] CHEN Li-gang,ZOU Feng-xing,XU Xiao-hong, Practical Teaching Reform in Computer Hardware Curriculums, Journal of EEE,vol. 2, 2013, pp.66-69

[2] RONG Ya-jun, WANG Wei, YUAN Ji-wei, SUN Yu-heng, Construction of Virtual, Proceedings of the CSU-EPSA, vol.24, 2012, pp.86-92

[3] LaboratoryYuran Jin, Yuping Chu, and Jianwei Dong.Research on th e Teaching Reform of Supply Chain Management Course in Network Environment. CSEE2011, Part V, CCIS 218, pp. 227-232, 2011

[4] WANG Chun-xia, Practice of Task driving TeachingMode under Network Environment in "Computer Application Foundation", Journal of Ningbo Radio \&TV Uinversity, vol.5, 2007, pp.89-92

[5] ZHAO Cheng-ling JIA Yong-na CHENG Ming-feng, Research aboutInstructional Design oftheExperimental Course of Educational Technology based on the Task-drivenApproach, Modem Educational Technology, vol. 21, 2011, pp.142-148 